\title{
Sacred Characters and Ritual Drama.The Synchretic Spiritual Background of The Discourse on the Eighth and Ninth,i.e. the Nag Hammadi Codex VI.6 ( $\left(^{\text {st }}\right.$ century AD).
}

\author{
Renata-Gabriela TATOMIR \\ Hyperion University - Bucharest
}

\section{The Discourse on the Eighth and Ninth (NH VI, 52, 1-63-63, 32 ${ }^{1}$ )}

From the very beginning it must be said that the title for the tractate $N H$ VI, 52,1 - 63,32 has been lost. Mahé suggests this may be ('O lÒgos) peri tñj 'Ogdoádoj kai tñj غ̇nneadój. ${ }^{2}$ The treatise - which is most likely to have been written between $\mathrm{I}^{\text {st }}-\mathrm{II}^{\mathrm{nd}}$ centuries A.D., though the known copies date back to the $\mathrm{IV}^{\text {th }}$ century A.D. - has been termed a Hermetic logos of instruction because of the references to Hermes and Trismegistus $(59,11.15 .24-25)$. The name given by the modern scholars, i.e., The Discourse on the Eighth and Ninth, is derived from its contents, since its ancient form has not been preserved at the opening or ending of the text. Titles for parts of the treatise may be inferred though in 53, 24-26 'discourse on the eighth and the ninth' ${ }^{3}, 56,27-28$ 'the vision of the eighth and the ninth'4, and in 61, 21-22 'The Eighth Reveals the Ninth's. The importance of the document lies in the connection between the spheres of the universe and the soul's journey beyond the material world to reach the divine realms. Either in life or in death, this was an initiatic scenario and process which contains a mixture of ancient Egyptian and synchretic traditions and rituals, mainly dualistic Gnostic themes and mystery elements which should not be ignored. ${ }^{6}$ To reach the spiritual enlightment and the realms of the divine, the initiate's soul would first journey through the seven spheres which in ancient times were thought to be the realms of the sun, moon, and planets, the lower powers whose control over human

Classical Papers, vol. xi , 2012 


\section{Sacred Characters and Ritual Drama}

life was not necessarily benevolent. ${ }^{7}$ Next, after successful passage, the soul would reach the highest eighth and the ninth spheres arriving in the divine realms, the levels at which it could experience true bliss, ${ }^{8}$ and coming to regions controlled by the God who gives life. Without a doubt the Coptic text is a translation from a Greek original and constitutes a rite of initiation into the mysteries of Hermes Trismegistus. The technique employed is that of teaching through ritual. The spheres mentioned, the eighth and the ninth particularly, indicate levels of Reality reached by the soul through a complex process of transformation of state by means of initiatic rituals. Therefore, the eighth and the ninth spheres may suggest either the advanced stages of spiritual development, or the very structure of All - or both. In a formal sense, The Discourse on the Eighth and Ninth is a dialogue between a teacher or mystagogue, Hermes Trismegistus (Thricegreatest Hermes, the "father"), and a pupil - the initiate - called the "son", without giving him any other particular name. ${ }^{9}$ The mystagogue instructs the initiate in the secret knowledge and guides him into an ecstatic experience of the divine, manifested as the Eighth and the Ninth realms, i.e. the Ogdoad and the Ennead.

The document is both an instruction and ritual drama. The instruction scenario follows an order which is very clearly marked. For a keen observer its steps are very much alike to those followed by a playwrighter, and more precisely by one trained in the ritual plays of the Mysteries religions. In Late Antiquity these were so appreciated that it has been suggested by some modern scholars that any other texts of the period may have been written to serve a mystagogic purpose. We are near the world of Reitzenstein's Lese-Mysterium, defined by Reitzenstein with reference to the Corpus Hermeticum. According to Reitzenstein, the author of a Hermetic text "hopes that, if God wills it and if the reader of the book has turned away from the world, his presentation will exert upon the reader the same effect as an actual mystery. The reader is to experience such a mystery in his imagination." Again, "the sacred action is supposed to be achieved, and can be achieved, within the reader during the reading of the 


\section{Renata-Gabriela TATOMIR}

document. . . . The experience of the first divine founder is related, in order to operate upon the reader by the magic of analogy." in both the Corpus Hermeticum and The Discourse on the Eighth and Ninth are likely to have functioned as preparation for, recollection of, or even substitutes for initiatory rites. ${ }^{11}$ However, they may have also been performed by the members of small mystic communities as part of its life in general and of each of its elected members in particular.

In short, as Mahé has detailed, ${ }^{12}$ the discourse on the eighth and ninth follows the strict order of a play with only two characters.:

- In the Preamble, the disciple remembers Hermes the promise he made him to "bring his mind into the eighth and afterwards into the ninth" following the "order of tradition"(NH VI.6, 52, 5);

- The master then reveals the source of his power to the disciple, a power able to bring the intellect of the initiate into the highest spheres of the divine.

- The new initiate learns that he belongs to the race of the elected ones, spiritual beings which all come from the same father; these elected ones "exist as forces that grow other souls" and therefore "are immortal". (NH VI.6, 52, 22) The disciple must recognize them and then be unified with them in order to pray the father of the universe "that he may give the spirit of eloquence".(NH VI.6, 52, 31)

- Now follows the mystic enlightment, that means the prayer addressed by Hermes and his unnamed disciple to the invisible God of the universe. Through a common silent prayer they ask him to give them the favour of contemplating the Ogdoad and the Ennead, and spell for the first time the name of the invisible God as a long series of vowels.

- The next action - which looks like a ritual one - is to embrace each other affectionately. This is the moment of the enlightment of the master and the disciple, when both experience the power which is light followed by the vision of the Ogdoad, within angels and souls sing a hymn in silence.

- Prayer of the disciple addressed to a deified Hermes, identified with Trismegistus and with the God Noûs. 


\section{Sacred Characters and Ritual Drama}

- The second enlightment. Contemplating in silence, the disciple sees a much clear vision in Hermes-Noûs of the souls of the Ogdoad singing a hymn to the Ennead and its powers. Then he sees the invisible God, the Creator of those that are in the spirit.

- The next stage for the apprentice is to praise the Divine by singing a second hymn in silence, calling the name of the God that is hidden within him and utters for the second time the mysterious name of the God, as a long series of vowels.

- The final part of the document includes two actions: first, Hermes instructs the disciple to write a book for the temple of Hermes at Diospolis in hieroglyphic characters, entitled "The Eighth Reveals the Ninth", on a steles of turquoise. The steles must be guarded by eight guardians, the males on the right having frog-faces, and the females, on the left having cat-faces; second, the book must contain an oath for those who will read the book to guard the things that Hermes has said; and an imprecation formula against those who would dare to violate the oath.

The liturgical character of the document appears in a number of features such as: the avowed goal of divine rebirth; the titles "father" and "son" which are joined to other "brothers" and "citizens" in the ogdoad, or eighth realm; a ritual embrace $(57,26-27)$; a pattern of prayer $(55,23-57$, 25 ), which may be a literary intrusion); the final oath sworn by initiates to guard the secrets of Hermes. ${ }^{13}$

\section{The ancient Egyptian Ogdoad and Enneads}

As for the Eighth and Ninth, one must point out the ancient Egyptian background for these concepts. It is well known that in the ancient Egyptian theological systems, the Ogdoad was a system of eight deities, four gods and their consorts (the number four was considered to represent completeness). Each pair represented the male and female aspects of the four creative powers or sources. Nun and Naunet represented the primeval waters; Heh and Hauhet represented eternity; Kuk and Kauket represented darkness; and Amun and Amaunet represented air (or that which is hidden). 


\section{Renata-Gabriela TATOMIR}

The gods were all depicted with frog's heads, while the goddesses had the heads of serpents. Only Amun went on to be considered as more than a primeval force. While Nun was still referred to often, it was only as the representation of the waters of Chaos.

A certain amount of order was brought to Egyptian mythology and its myriad of gods by the priests themselves. The result of this was the creation of a number of enneads, groups of nine gods and goddesses, usually organized into families. The number nine was a sacred and symbolic number that could also stand for 'all' gods. This was because the Egyptians indicated plurals by using three, and nine was thus perceived as the plural of plurals. Therefore, 'nine' should not always be taken literally, the ennead of Thebes, for example, consists of fifteen gods. The most important ennead was that of Heliopolis, often called the Great Ennead. At its head was $\underline{\text { Atum, }}$, the creator and sun god. His children $\underline{\text { Shu }}$ and Tefnut gave birth to the earth god Geb and the sky goddess Nut, who in turn were

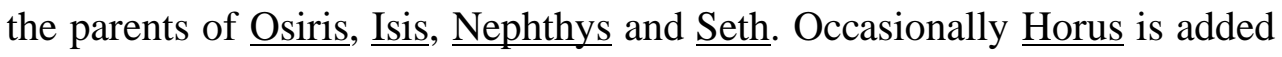
to them as a tenth god, sometimes as the fifth generation (child of Osiris and Isis) and sometimes as Nut's fifth child. In the Pyramid Texts of the Old Kingdom there is already mention of the five children of Nut. Centuries later, Plutarch relates how the sun god Helios (as the Greeks called the sun god $\underline{\mathrm{Re}}$ ) put a curse on the goddess Rhea (the Greek name for Nut), forbidding her to give birth to her children on any of the 360 days of the year. Hermes (Thoth in Egyptian) then added five days to the year (the five epagomenal days of the Egyptian calendar) and on these days Nut gave birth to her five children. In addition to the Great Ennead, there was also the Small Ennead, the gods of which varied with the times. The Small Ennead of Heliopolis included Isis's son Horus, Anubis, Maat and Thoth. Another Small Ennead included the Four Sons of Horus and the children of Khentekhtai. 


\section{Sacred Characters and Ritual Drama}

\section{Concepts related to drama and the sacred}

One may find useful at this moment to present some of the Greek concepts which we consider essential for the context we want to present in this paper: drama, theater, sacred, ritual, religion.

\section{Drama}

According to Storey and Allan, ${ }^{14}$ drama is action. The Greek word, $\delta \rho \subset \mu \alpha$ means "action," "doing," "performance." The two great philosophers of the fourth century, Plato and Aristotle, saw drama as an example of mimesis, "imitation" or "representation," but each took a different view of the matter. For Plato mimesis was something to be discredited, something inferior, which the ideal ruler of an ideal state would avoid. It meant putting oneself into the character of another, taking on another's role, which in many Greek myths could be a morally inferior one, perhaps even that of a slave or a woman. ${ }^{15}$ But Aristotle found in mimesis not only something natural in human nature but also something that was a pleasure and essential for human learning:

"to engage in mimesis is innate in human beings from childhood and humans differ from other living creatures in that humans are very mimetic and develop their first learning through mimesis and because all humans enjoy mimetic activities." (Aristotle, Poetics 1448b 5-9)

Drama then is "doing" or "performance," and in human cultures performances can be used in all sorts of ways. Religion and ritual immediately spring to mind as one context: the mystery religions and plays, which for a largely illiterate society would provide a venue for religious instruction and ritual reenactment, as well as for entertainment.

But drama can also encompass "knowledge" or "science" - for instance, the ancient Egyptian ritual sacred dramas performed within the temples may provide both a history of the creation of the world and a series of elaborate regeneration rituals for humans and nature as well. As such although the formal Egyptian temple re-presented a royal palace, it was also a focus for community gatherings as well as being an important cultural and economic multiplier for its specific area. The temple kept the vast majority

of the population at a distance from the vital daily cult rituals at the heart of 


\section{Renata-Gabriela TATOMIR}

the temple that fed and clothed the ensouled image of the deity, but it also invited the participation of the general population in large open-air festivals as well as providing a place for public prayer at the back wall of the temple, right behind the sanctuary, which represented the bedroom or throne ("great seat") of the god. Religious experience was based on "seeing" the god, but also knowing that the temple and it staff kept a "balance" (Maat in Egyptian) between the human and divine. This reciprocal arrangement was personified by the king (male or female) who was the transmission point between these two spheres. Successful balance maintained the necessities of life, made possible the flooding of the Nile and social stability where everyone kept to their proper social station and was gainfully employed in their appropriate occupation in a harmonious and non-threatening natural environment. $^{16}$

Then, in the same context, through myths and legends, drama and performance can keep historical events alive, particularly because more than myths legends are based on real "historical" events. ${ }^{17}$ Drama may help also to provide moral and spiritual instruction - and this is the case investigated in this paper - but not only. The scenarios played in the Mystery religions were meant to reiterate the message of the myth and of the divine characters people were playing. And finally humans enjoy both acting in and watching performances. ${ }^{18}$

\section{Theater and the Sacred}

Another significant concept for our discussion is "theater." In Greek thea- means "observe," "watch" (related also to "theory" as the result of mental contemplation), and while we speak of an "audience" and an "auditorium" (from the Latin audire, "to hear"), the ancients talked of "watchers," "spectators," and the "watching-place." The noun theatron ("theater") refers both to the physical area where the plays were staged, more specifically here to the area on the hillside occupied by the spectators, and also to the spectators themselves, much as "house" today can refer to the theater building and the audience in that building. ${ }^{19}$ Therefore, in our particular Hermetic context, the dialogue between the quasi-divine master and the disciple may have been exhibited and performed anywhere, even on 


\section{Sacred Characters and Ritual Drama}

an invisible stage, because it suggests the universal dimension of the divine, as well as the single spectator and character, which is the "son".

Theatre activates forms of knowing and stimulates ways of being and doing ${ }^{20}$ - many of which are currently more specifically approached under the heading of performance. If there is a sense in which the sacred is an entry to a particularly vital condition, then theatre - as a praxis - is one of the primary sites for its activation, and the forms and methods of theatre may lead to it and disclose what it is.

William S. Haney defines the sacred of theatre ${ }^{21}$ as a voiding of thought' (going beyond pairs of opposites) and a condition of liminality; and claims that the optimal subjective experience of liminality is performance (my underlining). D. E. R. George proposes that performance needs to be investigated as a particular kind of knowledge, and that it offers different ways to look at Time, at Space, at Person, at Knowledge, at Experience, ways which may be closer to both contemporary scientific research [Quantum Theory, Chaos, Complexity], and contemporary philosophical enquiry [Cognitive Science, Process Philosophy]. ${ }^{22}$

The instruction process in the secret knowledge to attain enlightment developed in NH VI.6 aimed to transform the elected one (the unnamed "son") by the master (Hermes) into a spiritual being. The vehicles of this performance are the dialogue, instruction, an earnest prayer and a silent hymn of praise to the divine, all meant to integrate the initiate into the assembly of immortals, i.e., "the spiritual ones" [...] which "exist as forces that grow other souls" and therefore "they are immortals". ${ }^{23}$ That is the way in the "order of the tradition" 24 " the elected one can reach the levels of the Ultimate Reality, the Eighth and Ninth i.e., the Ogdoad and the Ennead. And in that form this is the final goal of every ritualic scenario of the Mystery religions: to take the receiver out of the ordinary, this is the task here, not just in the sense of presenting something slightly unusual, but much more 'radically' or fundamentally opening up the capacity for seeing anew, for beginning to get in on the way things put themselves together. To do that, one has to go 'back' to 'before' preconceptions, to a 'place' 'prior 


\section{Renata-Gabriela TATOMIR}

to' language, (in our case, the Eighth and the Ninth), what Peter Malekin calls 'emptiness...devoid of boundaries.' Shock may be one aspect of the process, since it may well be a shock to find oneself 'outside' what one thought of as oneself and the configuration of the known world; it may also be a case of loss or abjection, a sudden revelation of the emptiness of role and identity. However, it may also be a gap of amazement. ${ }^{25}$

The sacred of the theatre performance may be its capacity to activate a particular quotient of energy, a form of active and holistic knowing, qualitatively different from 'normal' discrete subject/object cognition. This type of approachment points to quantum physical models which give precedence to energy-events rather than matter as the fundamental constituents of 'reality' (which is always in process, not a static given). ${ }^{26}$

\section{Ritual}

The school of the Cambridge anthropologists explained myth as developing out of ritual. We worship a certain way, do and say things in a certain ordered and repeated pattern, often for reasons unknown, and myths were told to explain the details of that ritual. ${ }^{27}$ By its very nature ritual is performed in the same way again and again. Drama may certainly use ritual, however, and more recent criticism has concentrated on how various rituals, familiar to and taken for granted by the audience, may impinge upon the drama and contribute to our understanding of them. ${ }^{28}$

From anthropology comes a type of study which considers the relationship of myth and ritual to drama. Both myth and ritual are important aspects of drama. In terms of drama's use of ritual, it is first necessary to familiarize oneself with the types of ritual and uses that were made of them in their more usual contexts. Here we are interested in both "religious" ritual and ritualized forms of civic behavior that have the force of religious belief behind them. Among others, these may include petitions for protection (supplicantions), imprecations, the swearing of oaths, rites of passage (e.g., initiation, marriage, and funerary rituals), and hymns and prayers addressed to the gods. 


\section{Sacred Characters and Ritual Drama}

In the ancient Greek frame of reference at least one ritual or ritualized activity was used within the drama to frame or to carry forward the action. It is important to say that the original audience were intimately familiar with these rituals and their significance for the proper order within the polis. Therefore, for them the appropriateness or inappropriateness of its use in the play would have been immediately clear. ${ }^{29}$

By studying the way the rituals and ritualized behavior are built into the ancient dramas - either civic or ritual ones -, we may gain a fuller understanding of the multiple levels on which these plays communicated with their audiences. ${ }^{30}$

\section{Religion}

"Religion" was the term used by the modern scholars when referring to the set of beliefs and worship of the ancient world in general. To the modern ear, however, the word "religion" conjures up organized systems of formal rituals and creeds, a hierarchy of officials ("hierarchy" means literally "rule of the sacred"), or the sort of entry one checks off (or not) on a census form. In the ancient world the lines were not distinctly drawn between "religion", "philosophy", and "science", or "morality" or "ethics." Greeks worshiped their gods not from any sense of personal guilt or fervent belief or in an attitude of humility, but because the gods of their myths represented forces beyond humanity in the universe, forces which had control over mortals, and which (it was felt) could be influenced by human worship and offerings. The principle of do ut des ("I give so that you may give") lay behind the offering of sacrifices to the gods. ${ }^{31}$

Drama does have a religious dimension. For instance, in ancient Greece, its origins are traditionally assigned to the formal worship of the god Dionysos. Plays were produced as part of the festivals in honor of Dionysos, when the normal life of the city stopped and the life of carnival took over. Greek drama, however, like Greek myth in general, is more about human men and women. Gods appear on stage, intervene and influence the action, interact (often violently) with the human characters, but what interests the playwrighters is the human reaction. In the ritual 


\section{Renata-Gabriela TATOMIR}

plays of the ancient Egypt and Near-East the divine actions and reactions are emphasized, and their importance for the balance of the universe and the world. Along with the spiritual enlightment through knowledge of the divine and ritual performance, this last aspect was developed by Gnosticism, Neoplatonism, and Hermeticism.

Gods are immortal, gods have power, gods exist and are responsible in some way for the ways of the world. ${ }^{32}$ Therefore, their relationship with humanity, their actions and reactions, and the way the gods interfere with the material world represents an attempt to explore the meaning of life.

\section{Ritual -(and) drama}

There have been many attempts to establish firm criteria for distinguishing ritual and drama. Among those commnonly cited are the following differentiae: ${ }^{33}$

- ritual is religious, drama secular;

- in ritual all are participants, in drama there is a sharp division between actors and audience;

- ritual has a fixed text, drama a variable text;

- ritual is efficacious, drama is entertaining;

- in addition various contextual factors have often been cited. It has, for example, been argued that drama performs in complex state-level societies the function of ritual in smaller traditional communities, or that drama is an expression of a freer and more egalitarian society, whereas ritual suggests hierarchy and compulsion. ${ }^{34}$

However nowadays the categories of ritual and drama are not so much divided as joined by a continuum, and, indeed, anthropology has generated a third term that marks the very expansive middle range of this continuum, namely, "ritual-drama". Because it is hard to conceive of ritual without some element of drama or drama without some element of ritual. ${ }^{35}$ It is interesting that the synchretic traditions behind the NH VI.6 scenario seems fairy close to the middle ground of ritual-drama, emphasizing the strong ritual side of ritual-drama.

Last but not least, one may find interesting another element in the scenario of The Discourse on the Eighth and Ninth, which is the 


\section{Sacred Characters and Ritual Drama}

democratization of the spiritual enlightment process through ritual drama. While during the Age of the Pyramids only the pharaoh was thought to be the chosen one to gain spiritual enlightment and immortality - and that only after his death -, after twenty-five centuries and a complex synchretic social and political, cultural and religious development, one assists to the democratization not only of knowledge, but of the way one may gain access to the spiritual enlightment. This feature is clearly shown in the NH VI.6 dialogue between the master and the disciple, and lies in the simple fact that although the initiate is unnamed - which suggests that he may have any social status - he belongs to the community of elected ones. This gain was due to the Greek cultural influence during the Hellenistic period particularly, and has been enriched by the Gnostic and Neoplatonic elements.

\section{Notes:}

${ }^{1}$ According to Mahé 1978, I, 14.

${ }^{2}$ Mahé 1978, I, 14.

${ }^{3}$ Brashler, Dirkse and Parrott, 1977, 293.

${ }^{4}$ Brashler, Dirkse and Parrott, 1977, 294.

${ }^{5}$ Brashler, Dirkse and Parrott, 1977, 296.

${ }^{6}$ Brashler, Dirkse and Parrott $(1977,292)$ point out certain affinities with Middle Platonism which suggest a date of composition in the second century C.E.

${ }^{7}$ Brashler, Dirkse and Parrott, 1977, 292.

${ }^{8}$ Brashler, Dirkse and Parrott, 1977, 292.

${ }^{9}$ One knows that between the Hermetic logoi addressed to Tat there are writings where the name of the disciple does not appear in the dialogue. Cf. Festugière, 1981, II., 28-50.

${ }^{10}$ Griffiths 1999, 114.

${ }^{11}$ Griffith-Jones 2008.

${ }^{12} 1978$, I, 31-33.

${ }^{13}$ Brown, http://ccdl.libraries.claremont.edu/cdm/singleitem/collection/cce/id/752

${ }^{14}$ Storey and Allan 2005, 1.

${ }^{15}$ Storey and Allan 2005, 1.

${ }^{16}$ Gillam, Innes, Jacobson 2010, 2.

${ }^{17}$ Idem 2. 


\title{
Renata-Gabriela TATOMIR
}

\author{
${ }^{18}$ Idem, 2. \\ ${ }^{19}$ Idem, 2 \\ ${ }^{20}$ Yarrow, 2007, 14. \\ ${ }^{21}$ Yarrow apud Haney 2007, Part 2, Chapter 3. \\ ${ }^{22}$ Yarrow apud George, loc. cit. \\ ${ }^{23}$ Brashler, Dirkse and Parrott, 1977, 293. \\ ${ }^{24}$ Idem, 292. \\ ${ }^{25}$ Yarrow 2007, 15. \\ ${ }^{26}$ Idem 16-17. \\ ${ }^{27}$ Idem, 31. \\ ${ }^{28}$ Idem, 31-32. \\ ${ }^{29}$ Idem 235. \\ ${ }^{30}$ Idem 236. \\ ${ }^{31}$ Idem, 24. \\ ${ }^{32}$ Idem, 34. \\ ${ }^{33}$ Csapo and Miller 2007, 4. \\ ${ }^{34}$ Idem. \\ ${ }^{35}$ Csapo and Miller, op. cit., 4.
}

\section{Bibliograpy}

Brashler, J., Dirkse, P. A., and Parrott, D. M. (Introduction and translation.) 1977. "The Discourse on the Eighth and Ninth" (VI.6). The Nag Hammadi Library in English. Translated by James M. Robinson. Leiden. 292 - 297.

Brown, K. S. Discourse on the Eighth and Ninth, sixth tractate in Codex VI of the Nag Hammadi Library. http://ccdl.libraries.claremont.edu/cdm/singleitem/collection/cce/id 1752 .

Csapo, E., Miller, M. C. (eds.) 2007. The Origins of Theater in Ancient Greece and Beyond: from Ritual to Drama. Cambridge University Press.

Festugière, A. J. 1981. La révélation d'Hermès Trismégiste. Tome II. Le dieu cosmique. Paris. 


\section{Sacred Characters and Ritual Drama}

Gillam, R., Innes, C., Jacobson, J. 2010. "Performance and Ritual in the Virtual Egyptian Temple". Proceedings of the $38^{\text {th }}$ Conference on Computer Applications and Quantitative Methods in Arcaeology, Granada, Spain, April.

Mahé, J.-P. 1978. Hermès en Haute-Egypte I. Les textes hermétiques de Nag Hammadi et leurs parallèles grecs et latins) (= Bibliothèque Copte de Nag Hammadi. Section «Textes » 3). Québec.

Mahé, J.-P. 1982. Hermès en Haute-Egypte II. Le fragment du Discous Parfait et les Definitions hermétiques arméniennes (NH VI, 8.8a) (= Bibliothèque Copte de Nag Hammadi. Section «Textes» 7). Québec.

Nock, A.D. / Festugière, A.-J. 1991. Corpus Hermeticum. Tome I ${ }^{7}$. Paris.

Malekin, P. 2007. "The Sacred, Drama, Ritual and the ancient Mystery Religions". Ralph Yarrow, Franc Chamberlain, Sacred Theatre. Part of the Theatre \& Consciousness Series. Bristol \& The University of Chicago Press.

Quispel, G. 2008. "Plotinus and the Jewish Gnōstikoi". Johannes van Oort, (ed.) Gnostica, Judaica, Catholica. Collected Essays of Gilles Quispel. Leiden, Boston. 583-626.

Griffiths, P. J. 1999. Religious Reading: The Place of Reading in the Practice of Religion. New York.

Griffith-Jones, R. 2008. "Transformation by a Text: The Gospel of John". Frances Flannery, Colleen Shantz, and Rodney A. Werline (eds.), Experientia, volume I. Inquiry into Religious Experience in Early Judaism and Early Christianity. Atlanta. 105-124.

Storey, I. C. and Allan, A. 2005. A Guide to Ancient Greek Drama. Blackwell Guides to Classical Literature, New York.

Yarrow, R. 2007. "Overture" in "What is Sacred". Ralph Yarrow, Franc Chamberlain, Sacred Theatre. Part of the Theatre \& Consciousness Series, Bristol \& The University of Chicago Press. 